\title{
Informationssogeadfardens betydning og workshop-metodens anvendelighed ved design af metadatasystemer
}

\author{
Af Heidi Friis Thomsen
}

\section{Introduktion}

Håndteringen af elektroniske dokumenter spiller en stadig større rolle i organisationer. For at kunne skabe informationssystemer, der stemmer overens med brugernes behov og arbejdssituationer er det nødvendigt at foretage indledende IT-forundersøgelser som grundlag for bæredygtige informationssystemer (Bødker et al., 2000). Denne artikel bygger på en undersøgelse der blev gennemført i forbindelse med mit kandidatspeciale ved Danmarks Biblioteksskole, foråret 2003.

Formålet med undersøgelsen i specialet var at skabe grundlag for udviklingen af et metadatasystem til en konkret videnvirksomhed. Metadata knytter sig til indeksering (Lykke Nielsen, 2002), og således havde specialet fokus på indeksering og metadata. Specialet beskæftigede sig ikke med systemdesign på et generelt plan.

Udgangspunktet for at kunne designe bruger- og domænetilpassede metadatasystemer er et indgående kendskab til brugernes informationsbehov og deres informationssøgeadfærd (Ingwersen, 1992; Allen,
1996), men litteraturen giver ifølge Lykke Nielsen (2000) ikke mange evalueringer af dataindsamlingsmetoder anvendt med henblik på systemdesign. I specialet blev undersøgt hvorvidt workshop er en anvendelig dataindsamlingsmetode til undersøgelse af informationsbehov og informationssøgeadfærd med henblik på design af metadatasystemer. Workshoppen skulle bruges til at belyse undersøgelsesdeltagernes informationsbehov og informationssøgeadfærd med henblik på efterfølgende at gøre det muligt at definere metadatasystemets rammer og indhold herunder også at foretage indekseringen til systemet. En workshop bygger på interaktion mellem flere deltagere, og som følge heraf giver metoden mulighed for at skabe refleksion hos deltagerne. Herved er der mulighed for at få indblik i deltagernes bevæggrunde og tanker (Kvale, 2000, s. 40). Der ligger således en potentiel dynamik og synergieffekt i workshoppen, som måske vil kunne give et holistisk billede af søgeprocessen til brug ved konstruktion af informationssystemer. Derfor har jeg fundet det interessant at undersøge workshoppens anvendelighed i indsamling af data til brug ved systemdesign. 
På baggrund af specialets konklusioner diskuteres i denne artikel indledningsvist hvilke informationer om informationsbehov og informationssøgeadfærd det er relevant at indsamle som grundlag for at designe et bruger- og domænetilpasset metadatasystem. Dernæst diskuteres evalueringsarbejdet omkring workshoppen.

Specialet og dermed artiklen er motiveret af forskningen $\mathrm{i}$ informationssøgeadfærd. To centrale forskningsområder indenfor informationsvidenskaben beskæftiger sig med informationssøgning, men med hvert sit fokus (Vakkari, 1999).

Det ene forskningsområde betegnes Information Seeking (IS) og har fokus på brugerne, deres brug af kilder i informationssøgning samt deres anvendelse af den fremfundne information (Vakkari, 1999). Resultaterne af denne brugerorienterede forskning har dog ikke været anvendt i praksis til design af informationssystemer (Vakkari, 1999).

Det andet forskningsområde er Information Retrie$\mathrm{val}^{1}$ (IR), der har fokus på genfinding af relevante informationsobjekter. Det betyder, at interessefeltet er at optimere informationssystemet, så det kan støtte brugeren bedst muligt i søgeprocessen (Vakkari, 1999). Disse forskningsområder har været skarpt adskilte (Vakkari, 1999), men flere (bl.a. Ellis, 1989; Ingwersen, 1992; 1996; Vakkari, 1999; Wilson, 1999) understreger behovet for at forbinde resultater fra de to grene og udnytte disse til et systemdesign, der bygger på et mere holistisk billede af brugeren i informationssøgningsprocessen. Det er dette der arbejdes ud fra i artiklen.

\section{Domæneanalyse}

Når man ønsker at udarbejde et brugerorienteret og domænetilpasset informationssystem, er det vigtigt at indlede designet med en analyse af det arbejdsdomæne, systemet skal bruges $i$, dets brugergruppe og de funktioner i organisationen, systemet skal støtte (Bødker et al. 2000; Lykke Nielsen, 2002).
Lykke Nielsen (2000) peger på, at domæneanalysen skal tilvejebringe to typer af viden som grundlag for systemdesign: Domæneviden og konceptuel viden.

Domæneviden, der er essentiel for at kunne definere og designe informationssystemet, "...covers knowledge about the environment and the situations in which the [system $]^{2}$ is going to be used, knowledge about work tasks, knowledge about information use and information needs, and knowledge about the different approaches to the subject field" (Lykke Nielsen, 2000, s. 3).

Den konceptuelle viden er vigtig i relation til indeksering til systemet. Den skal give mulighed for at vælge, kontrollere og strukturere vokabularet $i$ informationssystemet. Konceptuel viden er: “...linguistic, semantic knowledge about naming, form, meaning and relations between concepts and terms" (Lykke Nielsen, 2000, s. 3).

\section{Informationsbehovets betydning}

Et informationsbehov opstår typisk når individets videnstrukturer ikke længere rækker til at forstå den situation det står i og individet må skabe en ny forståelse (Allen, 1996; 1997; Belkin et al. 1982; Dervin og Nilan, 1986; Kuhlthau, 1991). Ofte vil individet søge information, så situationen atter bliver forståelig. Videnstrukturerne vil udvikle sig undervejs i søgeprocessen efterhånden som søgeprocessens resultater giver individet mulighed for at revurdere det informationsbehov der indledte søgningen.

Ifølge Allen (1996; 1997) er individet formet af en række individuelle faktorer - eksempelvis uddannelsesmæssig baggrund og personlige erfaringer - samt af en række sociale og kulturelle faktorer - eksempelvis det sociale tilhørsforhold og den organisatoriske kontekst det indgår i. Disse individuelle og situationelle faktorer påvirker individets måde at opleve sin situation på. Det betyder dermed også at informationsbehovet og -søgningen påvirkes af disse faktorer, hvorfor det er nødvendigt at undersøge dem som grundlag for et brugertilpasset systemdesign. De 
individuelle og situationelle faktorer kan på samme tid udgøre potentielle muligheder og barrierer $i$ informationssøgningen. Individets uddannelsesmæssige baggrund kan eksempelvis være en styrke for søgeprocessen da uddannelsen kan betyde et godt kendskab til terminologien i arbejdsdomænet. Omvendt kan manglende faglige kvalifikationer udgøre en barriere hvis individet mangler kendskab til terminologien og dermed ikke har evnen til at udvide sine søgninger med flere termer eller trække søgningerne op på et mere generelt niveau.

På samme vis kan den organisatoriske kontekst være af betydning for om informationssøgning prioriteres højt i organisationen, om arbejdsopgaverne afstedkommer komplekse informationsbehov o.l. Viden om sådanne situationelle faktorer er eksempelvis central i forhold til at vurdere hvor mange ressourcer der skal lægges i udviklingen af metadatasystemet og i forhold til at vurdere hvor komplekst metadatasystemet skal være for at støtte medarbejderne $i$ informationssøgeprocessen.

Det er relevant at identificere sådanne individuelle og situationelle faktorer for informationssøgeprocessen da det giver systemdesigneren mulighed for at tage hensyn til de barrierer der måtte være for brugerens informationssøgning i designet af metadatasystemet.

Eksempelvis vil man kunne tage hensyn til forskellige uddannelsesmæssige forudsætninger for at bruge informationssystemet ved at indarbejde definitioner af begreber i systemet, eksempelvis vha. en tesaurus, så alle medarbejdere, uanset hvilket vidensdomæne de kommer fra, gives mulighed for at forstå sprogbrugen i systemet. Eller man vil kunne støtte de svage videnstrukturer ved at skabe en browsingstruktur der giver brugeren mulighed for at tilgå systemet med et minimum af konceptuel viden. Ved at navigere rundt i systemet vha. associative links gives brugeren således mulighed for at udvikle sine videnstrukturer. Denne udvikling kræver naturligvis at systemet indeholder den fornødne konceptuelle information, præsenteret præcist og forståeligt for brugeren, samt at brugeren er villig til at handle interaktivt.

Da barrierer for søgeadfærd må forventes at skifte over tid og med de personer, der søger information i systemet, vil det ikke være muligt at tage hensyn til samtlige barrierer i designet af systemet. En hensyntagen til samtlige barrierer vil i de fleste tilfælde gøre systemet meget komplekst at bruge og urealistisk dyrt at udvikle.

Med udgangspunkt i arbejdsdomænet er det naturligt at undersøge de arbejdsfunktioner og herunder de typer af informationsbehov informationssystemet skal støtte (Lykke Nielsen, 2002). Eksempelvis kan nogle af de dokumenter medarbejderne bruger i det daglige inddrages i undersøgelsen. Hermed undersøges hvordan dokumenterne bruges og hvordan de skal kunne håndteres af systemet (Lykke Nielsen, 2002). Deltagerne vil med dokumenterne i hånden kunne fortælle hvilke informationsbehov, der vil udløse søgning af et sådant dokument, hvad de vil søge på for at finde dokumentet, såvel attributter som termer og hvordan de ville bruge dokumentet til løsning af deres problem. På denne vis vil diskussionen blive håndgribelig for såvel deltagere som undersøger.

Man kan tale om tre typer af informationsbehov; verifikative behov, bevidst emneafgrænsede behov og mudret afgrænsede behov (Ingwersen, 1992). I et verifikativt informationsbehov ønsker brugeren at verificere eller lokalisere et bestemt informationsobjekt (Ingwersen, 1992, s. 116) - f.eks. et forfatternavn, en adresse, et tidsskriftnavn osv. - og systemet kan støtte denne type behov ved at indeksere sådanne karakteristika. Brugerens begrebsmæssige videnstrukturer indeholder de data, der er nødvendige for at udtrykke behovet. Denne type behov forbliver typisk stabilt i løbet af søgeprocessen. I det bevidst emneafgrænsede behov ønsker brugeren at opnå afklaring, at bedømme eller at søge ny information om et kendt emne (Ingwersen, 1992, s. 117). Dette behov kan forblive stabilt i løbet af processen eller det kan ændre sig efterhånden som brugerens søgning udvikler sig. Det mudrede emneafgrænsede informationsbe- 
hov kan opstå, hvor brugeren ønsker at udforske et ukendt område (Ingwersen, 1992, s. 117). Det kan f.eks. være en forsker, der ønsker at opspore mulige løsninger på et problem, men ikke har nogen ide om, hvordan han skal udtrykke behovet. De begrebsmæssige videnstrukturer er svage (eller mudrede) eller eksisterer simpelthen ikke i relation til den efterspurgte potentielle information. Dette behov udvikler sig undervejs i søgeprocessen og kan støttes ved at systemet indeholder en fyldig beskrivelse af informationsobjekterne og giver mange indgange til søgning - f.eks. ved indeksering af en række forskellige karakteristika ved informationsobjekterne.

Uanset om informationssøgeren er bevidst om sit informationsbehov eller ej, tager informationssøgerens forespørgsel form af en etikette, der består af et eller nogle få begreber, der ofte er generelle eller ude af kontekst med det egentlige informationsbehov (Ingwersen, 1982, s. 178). Dette skyldes at brugeren styres af sine forventninger til systemet og kan have vanskeligt ved at udtrykke sit behov i den sprogbrug systemet fordrer.

Etikette-effekten er påvirket af individuelle og situationelle variabler, og det kan dermed være vanskeligt at afhjælpe denne effekt. Men man kan delvist kompensere for etikette-effekten ved at sikre at specificiteten af indekseringen til informationssystemet modsvarer emneområdets kompleksitet, brugernes sprogbrug og forståelse for emnet.

Arbejdsopgaver kan være mere eller mindre komplekse. Byström og Järvelin (1995) har undersøgt, hvordan kompleksiteten i arbejdsopgaver påvirker informationssøgning. De grupperede arbejdsopgaverne blandt en medarbejdergruppe i kategorier efter i hvor høj grad løsningen af arbejdsopgaven var givet på forhånd og processen i princippet kunne automatiseres. Byström og Järvelin (1995) viste, at jo mere komplekse opgaverne var, og dermed jo vanskeligere det var at bestemme løsningen på forhånd, jo mere komplekst blev informationsbehovet og dermed også informationssøgeprocessen.
Arbejdsopgavens og dermed også informationsbehovets kompleksitet har således også betydning for hvor komplekst et informationssystem, der er behov for. Skal systemet f.eks. kun hjælpe til at løse opgaver af verifikativ karakter, behøver det eksempelvis ikke give mulighed for emnesøgning, mens det til komplekse opgaver skal give brugeren mulighed for at anvende en række forskellige faciliteter, så det bliver muligt at tilgå problemet fra forskellige vinkler - herunder også mulighed for emnesøgning.

\section{Informationssøgeadfærdens betydning}

Den faktiske informationssøgeproces bør også have indflydelse på systemdesign. Kendskab til adfærden i søgeprocessen skal bruges til at skabe faciliteter i systemet der reflekterer denne adfærd og kan fungere som støtte for brugerens informationssøgeadfærd (Allen, 1996; Ellis, 1989; Ingwersen, 1992).

Når informationsbehovet er dynamisk og udvikler sig undervejs i søgeprocessen, må søgeprocessen være en heuristisk proces, hvor brugeren løbende justerer sin søgning på baggrund af de resultater, der er opnået undervejs. Dette stiller krav til informationssystemet. Outputtet fra søgningen må indeholde feedback på brugerens forespørgsel - eksempelvis i form af lister over termer, som brugeren kan anvende til modificering af søgningen (Ingwersen, 1992, s. 78). Sådanne faciliteter vil kunne støtte udviklingen af brugerens videnstrukturer og dermed udviklingen i søgeprocessen.

Hvordan brugerne finder frem til og anvender informationskilder til løsning af problemsituationer har betydning for systemdesign (Allen, 1996; Ellis, 1989). Et sådant kendskab kan give viden om hvilke funktioner brugerne har behov for i informationssystemet. Endvidere kan det vise hvilke karakteristika ved dokumenterne, det er hensigtsmæssigt at indeksere. Brugere der viser sig ofte at gøre brug af bestemte afsnit i en dokumenttype vil eksempelvis have behov for at dette afsnit indekseres i systemet. Hvilke kilder brugerne anvender, vil afhænge af den problemsituation de står i og af det opståede infor- 
mationsbehov samt af de personlige og situationelle variabler, der påvirker brugerne (Allen, 1996; 1997). En central kilde til information er dokumenter (Byström og Järvelin, 1995; Ellis, 1989; Ellis et al. 1993; Hertzum, 2000; 2002). Det er relevant at vide hvilke typer af dokumenter brugerne anvender i informationssøgeprocessen og hvordan de anvender dem. Denne domæneviden gør det muligt at bestemme indholdet i systemet samt at bestemme hvilke karakteristika ved dokumenterne, der skal indekseres.

En anden væsentlig kilde til information kan være personlige kontakter, hvor der trækkes på disse kontakters tidligere gjorte erfaringer (Hertzum, 2002). Hvis informationssystemet skal støtte en sådan adfærd er det nødvendigt at arbejde på at registrere disse kontakter eller deres erfaring så det er søgbart (Hertzum, 2002).

Ellis (1989) og Ellis et al. (1993) har gennem empiriske undersøgelser af søgeadfærden blandt naturvidenskabelige og samfundsvidenskabelige forskere identificeret 8 kategorier, der indeholder de væsentligste karakteristika ved informationssøgningen:

- Starting Brugeren begynder informationssøgeprocessen ved eksempelvis at konsultere personlige kilder, ved at studere referencelister, abstracts eller lignende. I denne fase er brugernes videnstrukturer mere eller mindre udviklede og dermed i høj grad bestemmende for, hvorledes brugeren vælger at gribe søgningen an. Undervejs i søgeprocessen udvikler videnstrukturerne sig typisk, hvilket også ses af de følgende kategorier.

- Chaining Brugeren følger citationer i kendt materiale, gør brug af citationsindekser eller følger andre relationer mellem materialer.

- Browsing Brugeren søger semi-struktureret i områder af potentiel interesse. F.eks. kunne det være at identificere relevante tidsskrifter i en samling.

- Differentiating Brugeren relevansvurderer materiale på baggrund af de forskellige kilders karakteristika.
- Monitoring Brugeren overvåger et bestemt område ved regelmæssigt at konsultere bestemte kilder.

- Extracting Brugeren arbejder sig systematisk gennem en bestemt kilde for at lokalisere materiale af interesse.

- Verifying Brugeren checker informationens nøjagtighed.

- Ending Brugeren foretager en afsluttende søgning, hvor løse ender samles. Eksempelvis i slutningen af et projekt, hvor brugeren vil have den nyeste information med.

Identifikation af sådanne karakteristika ved brugernes adfærd i søgeprocessen kan bruges til at tilpasse systemet til brugerne. Brugere der i undersøgelsen viser sig at browse meget, har brug for at man kan søge i systemet i en emnestruktur vha. hyperlinks; en bruger, der regelmæssigt overvåger udviklingen indenfor et bestemt emne kan have brug for at systemet automatisk kan foretage søgninger $\mathrm{i}$ en fastlagt brugerprofil, eller en bruger, der gør flittigt brug af chaining kan have stor fordel af at kunne foretage citationssøgninger i systemet eller få vist referencelister til dokumenter.

\section{Interaktion med informationssystemer}

Ved design af bruger- og domænetilpassede informationssystemer er det vigtigt at få kendskab til brugernes konceptuelle viden - eksempelvis anvendelse af begreber og begrebsrelationer i arbejdsdomænet (Lykke Nielsen, 2002). Mangler brugeren viden om emnet og den sprogbrug der karakteriserer det, kan vedkommende have vanskeligt ved at udtrykke sit informationsbehov til systemet (Lykke Nielsen og Ingwersen, 1999). Som nævnt udtrykker brugere ofte deres informationsbehov i brede, generelle termer, når de skal formulere deres forespørgsel til systemet (Ingwersen, 1982, s. 178). Dette er i konflikt med indekseringen i mange databaser (Lykke Nielsen og Ingwersen, 1999). Indekseringen til databaser er ofte specifik, og anvendelse af generelle termer vil således ikke føre til et match på brugerens fore- 
spørgsel. Det er nødvendigt, at specificiteten i indekseringen matcher specificiteten i brugerens valg af termer. Således må den indekseringsstrategi og det indekseringssprog, der anvendes til systemet, tage udgangspunkt i brugerens sprogbrug og forståelse for emneområdet. Endvidere kan systemet indeholde faciliteter som eksempelvis tesauri, der kontrollerer sproget og kortlægger begrebsrelationer, som støtte i søgningen.

Da brugernes informationsbehov ofte er komplekse, synes det vanskeligt at et enkelt eller få søgetermer $i$ en forespørgsel modsvarer det informationsbehov, brugerne oplever. Systemet kan med fordel have indbygget en form for relevansfeedback eller give søgeren mulighed for at tilføje flere termer i søgningen ved at foreslå yderligere termer på baggrund af den oprindelige forespørgsel (Ingwersen, 1992). Ved relevans-feedback modificeres brugerens forespørgsel automatisk af systemet på baggrund af statistiske beregninger af de tidligere fundne relevante eller ikkerelevante informationsobjekter (Ingwersen, 1992, s. 78).

Det kan endvidere være hensigtsmæssigt at være bevidst om, hvorvidt brugerne er erfarne $i$ at søge informationer elektronisk (Ingwersen, 1992). Erfaringsniveauet bør få betydning for i hvor høj grad brugeren har behov for støtte i søgningen og for hvilken type støtte brugeren har behov for.

\section{Sammenfatning}

Som det fremgår, er der en række faktorer omkring informationsbehovet og informationssøgeadfærden, der skal tages hensyn til, når man designer informationssystemer. Det er således nødvendigt at få belyst følgende faktorer, hvis man ønsker et holistisk billede af informationssøgeprocessen:

- Brugerkarakteristika - ex. uddannelsesmæssig baggrund, arbejdserfaring, viden om begreber og begrebsrelationer

- Arbejdsopgavens karakter og kompleksitet

- Informationsbehovet - type, dynamik og kompleksitet
- Den organisatoriske kontekst

- Kilder til informationer

- Barrierer for informationssøgeadfærd

- Kendskab til informationssystemet - herunder sprogbrug i systemet

\section{Workshoppen som metode}

I specialet undersøgtes ovennævnte faktorer omkring informationsbehovet og søgeadfærden vha. en workshop. Undersøgelsen blev tilrettelagt med henblik på at skabe et holistisk billede af deltagernes informationssøgeproces til brug for design af et metadatasystem.

Workshoppen er en kvalitativ dataindsamlingsmetode. Kvalitative dataindsamlingsmetoder anvendes til indsamling af informationer om holdninger og adfærd hos individer eller i organisationer, ved at undersøgeren forsøger at forstå de involverede personer, deres ritualer, overbevisninger og følelser (Nachmias og Nachmias, 1987, s. 287). Dette tyder således på at workshoppen vil være anvendelig til at indsamle information om de individuelle og situationelle variabler der som nævnt har afgørende betydning for adfærden i informationssøgeprocessen. I kvalitative undersøgelser beskæftiger man sig ofte med nogle få undersøgelsesdeltagere, der er udvalgt på baggrund af deres viden om emnet og ikke fordi de er statistisk repræsentative (Holm, 1997). Det er vigtigt at se evalueringen af workshoppen i dette lys og undlade at generalisere resultaterne ukritisk.

Workshoppen blev designet med udgangspunkt i metodeteori (Bødker et al., 2000; Effektive offentlige arbejdsprocesser, 1999) og i henhold til kravene om validitet og reliabilitet i kvalitativ dataindsamling (Nachmias og Nachmias, 1987). Der er fem trin i tilrettelæggelsen af en workshop: Planlægning $\rightarrow$ Forberedelse $\rightarrow$ Gennemførelse $\rightarrow$ Dokumentation $\rightarrow$ Verificering (Effektive offentlige arbejdsprocesser, 1999). Hvordan man griber tilrettelæggelsen an afhænger af hvad man vil opnå med workshoppen. Afgørende for projektets succes er dog, at deltagerne føler ejerskab for projektet (Bødker et al., 2000). 
Workshoppen blev i specialet tilrettelagt med udgangspunkt i deltagernes arbejdsdomæne. Undersøgelseselementerne informationsbehov og informationssøgeadfærd blev operationaliseret til 5 diskussionsoplæg og ud fra disse diskussionsoplæg skulle deltagerne fortælle historier fra deres hverdag om deres arbejdsopgaver, informationssøgeadfærd o.1. Til støtte for diskussionsoplæggene blev der udarbejdet en checkliste med uddybende spørgsmål. Disse spørgsmål blev udledt på baggrund af de undersøgelseselementer, der er udledt at teorien. Checklisten blev udarbejdet for at kunne vurdere om workshoppen indsamler de data det var tænkt, den skulle indsamle. Hvis ikke samtlige checklistespørgsmål besvares, betyder det at workshoppen ikke formår at indsamle den viden, der for denne undersøgelse er vurderet som essentiel. Man kan med andre ord ikke afvise workshoppen som metode på baggrund af en enkelt undersøgelse. Checklisten var ikke tænkt som interviewguide og fungerede ikke som sådan.

\section{Resultater}

Diskussionen omkring de planlagte oplæg var engageret og åben. Undervejs forholdt deltagerne sig til hinandens udsagn, kommenterede og byggede videre på fortællingerne, hvorved de i fællesskab fik konstrueret et billede af arbejdsdomænet og de personlige og situationelle variabler der påvirker det. Der opstod en synergieffekt der bevirkede, at workshoppen gav et nuanceret billede af deltagernes situation og behov. Den diskussion der opstod i workshoppen var god til at belyse de individuelle og situationelle variabler der påvirker deltagernes informationssøgeadfærd - herved opnåedes eksempelvis et godt indblik i de enkelte deltageres uddannelsesmæssige baggrund og følelser omkring deres arbejdssituation.

Med workshoppen indsamledes således en mængde domæneviden, der skal bruges til at definere og designe rammerne for metadatasystemet og den kontekst det skal indgå i. På baggrund af workshoppen blev det klart, at deltagerne som følge af deres ofte komplekse informationsbehov havde behov for et informationssystem med mange indgange og en browsingstruktur der kunne støtte deres ofte lidt famlende informationssøgning. De havde endvidere behov for at sprogbrugen i systemet blev kontrolleret da der blandt deltagerne var en udpræget brug af synonymer og varieret specificitet $i$ brug af termer. Et egentligt mønster i deltagernes sprogbrug fremkom ikke, hvilket betød at workshoppen ikke fik belyst den konceptuelle viden blandt deltagerne. Af workshoppens resultater kunne endvidere udledes en række behov for metadatafelter og attributter til metadatasystemet.

\section{Evaluering}

Ikke alle checklistespørgsmål blev lige udførligt besvaret og enkelte besvaredes slet ikke. Der mangler således flere informationer for at kunne udarbejde et fuldstændigt metadataformat på baggrund af workshoppens resultater. Der er behov for at opnå et mere indgående kendskab til medarbejdernes arbejdsopgaver og til deres måde at bruge information på i løsningen af arbejdsopgaverne. En dybere domæneviden vil gøre det muligt, mere præcist at udlede hvilke funktioner systemet skal understøtte - det være sig informationssøgning og genfinding, adgangskontrol, relationer mellem dokumenter og/eller versionsstyring m.m. Endvidere vil man mere specifikt kunne udlede hvordan dokumenter skal håndteres i systemet - eksempelvis hvilke attributter der skal beskrives og gøres søgbare.

Det var særligt checklistespørgsmålene til indsamling af konceptuel viden, der ikke blev besvaret. Der blev ikke opnået nogen egentlig indsigt i medarbejdernes sprogbrug og dermed de begreber og begrebsrelationer det findes i arbejdsdomænet i den konkrete videnvirksomhed. Denne viden ville gøre det muligt at udarbejde en indekseringsstrategi og et indekseringssprog til systemet; at vælge, kontrollere og strukturere vokabularet.

Der kan naturligvis være mange årsager til at en workshop som metode ikke altid får indsamlet alle relevante informationer. I relation til specialet er der 
også flere mulige forklaringer. En forklaring kan være at de to timer der var afsat til workshoppen var for kort tid til at få belyst alle spørgsmålene. En anden forklaring kan være de sociale relationer blandt deltagerne, hvor enkelte kan have følt sig underlagt én eller flere i gruppen og ikke har turdet udtale sig frit. En af cheferne deltog således i workshoppen sammen med sine medarbejdere. Chefen gav tydeligt udtryk for hvad ledelsen ville acceptere, hvor mange ressourcer han mente virksomheden ville ofre på et informationssystem osv.

Det er problematisk for dataindsamlingen, hvis en deltager skyder de øvrige deltageres holdninger og ideer i sænk, da det kan få betydning for kvaliteten af de indsamlede data. Man må som undersøger være opmærksom på sådanne forhold. I en workshop indtager undersøgeren rollen som facilitator, hvilket betyder at det er undersøgerens opgave at bidrage til fremdrift og udvikling i workshoppen uden at være styrende for processen (Bødker et al., 2000, s. 271; Effektive offentlige arbejdsprocesser, 1999). Hvis det viser sig nødvendigt er det dog væsentligt for resultatet af processen at undersøgeren tør gribe ind og overtage styringen, så det sikres at fokus holdes og alle får lov at fremsætte deres synspunkter.

Den manglende besvarelse af samtlige checklistespørgsmål kan også skyldes at diskussionsoplæggene ikke egnede sig til at sikre en droftelse af samtlige spørgsmål. Den gennemførte workshop tog ikke udgangspunkt i konkrete dokumenter fra deltagernes hverdag eller lignende, hvilket muligvis har bevirket at diskussionen blev for ukonkret og fremmed for deltagerne. Deltagerne ville ud fra dokumenterne kunne fortælle hvilke informationsbehov, der ville udløse søgning efter et sådant dokument, hvad de ville søge på for at finde det og hvordan de ville bruge dokumentet til løsning af problemet. Det sidste ville give vigtig information om eventuelle afsnit, der skal indekseres i dokumentet.

Det er endvidere vigtigt for workshoppens resultater at deltagerne har en erfaring med emnet som de kan og vil dele med andre. I undersøgelsen viste det sig at deltagerne sjældent søger information hos andre end de nærmeste kolleger og at informationssøgning er en ubevidst proces for dem. Derved bliver det vanskeligt for deltagerne at tale om informationssøgningen som noget konkret og så er det vanskeligt at indsamle denne type information vha. workshoppen. Det er i en sådan situation ikke nødvendigvis workshoppen som metode der fejler, men et spørgsmål om udformningen af workshoppen, der muligvis ikke er afstemt deltagernes forudsætninger.

På baggrund af resultaterne af den gennemførte workshop synes det nødvendigt, at undersøgeren forud for planlægningen af workshoppen har et godt indledende kendskab til den organisatoriske kontekst den skal gennemføres i. Dette kendskab skal undersøgeren tilegne sig i samarbejde med organisationen - f.eks. $\mathrm{i}$ indledende interviews med ledelsen. Undersøgeren skal vide lidt om organisationens arbejde, struktur og tekniske faciliteter. Endvidere skal vedkommende vide, hvor mange ressourcer organisationen er parat til at afsætte til workshoppen og udviklingen af informationssystemet, og om der generelt er opbakning til projektet i virksomheden. Det er vigtigt at såvel deltagere som ledelse føler ejerskab for projektet, da resultaterne ellers risikerer at blive forkastet (Bødker et al., 2000). Det kan vise sig dyrt at undlade disse indledende undersøgelser, hvis det viser sig at undersøgelsens resultater ikke kan anvendes til udvikling af et bruger- og domænetilpasset informationssystem. Eksempelvis er det spild af ressourcer at gennemføre en stort anlagt workshop, hvor man bruger meget tid på at identificere metadatafelter og attributter, hvis organisationen i sidste ende kun vil ofre penge på et informationssystem med mulighed for fritekstsøgning.

\section{Opsamling}

Det lykkedes at få indsamlet hovedparten af den domæneviden, der som nævnt er nødvendig for at kunne definere og designe et metadatasystem. Enkelte faktorer havde med fordel kunnet være belyst mere indgående. At ikke alt blev belyst kan sandsynligvis tilskrives designet af workshoppen og ikke umiddel- 
bart workshoppens potentiale som dataindsamlingsmetode.

Det lykkedes ikke at indsamle den konceptuelle viden via workshoppen. Der fremkom indikationer på sprogbrugen og enkelte potentielle emneord kunne identificeres, men noget egentligt mønster var der ikke tale om. Havde workshoppens formål alene være at belyse den konceptuelle viden ville det muligvis kunne lade sig gøre, men ikke i så "bred" en workshop som gennemført i undersøgelsen.

I artiklens første del udledes mange og meget forskelligartede faktorer som skal have betydning for systemdesign. Når de belyses vil de give et holistisk billede af søgeprocessen, hvilket er nødvendigt til brug ved systemdesign. Spørgsmålet er dog, hvorvidt faktorerne har været for mange og for forskelligartede til at kunne undersøges i én workshop af to timers varighed. Det er vanskeligt at svare på, men jeg mener, at det er tilfældet. Ifølge Vakkari (1997) er det nødvendigt at undersøge såvel individuelle som situationelle variablers påvirkning på søgeprocessen, men samtidig påpeger han, at det at inkludere samtlige variabler i én indgående undersøgelse "...would imply a research design which would be too complicated to be completed" (Vakkari, 1997, s. 463).

Derfor vil det sandsynligvis være hensigtsmæssigt at dele belysningen af samtlige undersøgelseselementer op i flere undersøgelser, hvis ikke undersøgelsesdesignet skal blive for komplekst. En ulempe ved en opdeling i flere undersøgelser kan dog være, at man mister sammenhæng og dermed ikke får skabt et holistisk billede.

\section{Konklusion}

Udgangspunktet for artiklen var at en række faktorer omkring informationssøgeadfærden bør have indflydelse på designet af bruger- og domænetilpassede metadatasystemer. Det bedste grundlag for designet af metadatasystemer er at skabe et holistisk billede af den informationssøgeproces, systemet skal støtte. Det betyder at såvel brugerne, deres brug af kilder i informationssøgning, deres anvendelse af informationer samt deres forståelse for og interaktion med informationssystemer skal undersøges. På baggrund af teorien om informationsbehov og informationssøgeadfærd blev der udledt en række konkrete undersøgelseselementer, der ved belysning samlet giver et holistisk billede af informationssøgeprocessen.

En undersøgelse af om dataindsamlingsmetoden workshop kan anvendes til at belyse disse elementer viste, at workshoppen i den udformning den havde, med de deltagere og i den organisatoriske kontekst den blev gennemført, fik indsamlet en overvejende del af den domæneviden, der er nødvendig for at kunne designe et metadatasystem. Workshoppen tyder således på at være en anvendelig metode til brug ved design af metadatasystemer. Jeg konstaterede at deltagerne gennem den fælles diskussion konstruerede et detaljeret billede af deres arbejdssituation og den afledte informationssøgeadfærd. Det tolker jeg som udtryk for en synergieffekt, der for mig at se er den væsentligste styrke ved workshoppen. Netop synergieffekten kan vanskeligt opnås ved andre mere individuelle dataindsamlingsmetoder. Synergieffekten kunne dog ikke bidrage til indsamling af den konceptuelle viden. Det kan muligvis være et udtryk for at workshoppen har skullet indsamle for mange, for forskelligartede informationer, og at det evt. er nødvendigt at gøre brug af flere dataindsamlingsmetoder for at få samtlige undersøgelseselementer belyst. Dette må flere undersøgelser af workshoppen som dataindsamlingsmetode vise.

\section{Noter}

1. I det der kaldes den klassiske IR eller den systemdrevne tradition (Ingwersen, 1992) betragtes informationsbehov som statiske og på forhånd givne behov, der uproblematisk lader sig udtrykke i en forespørgsel (query) til systemet. Output fra systemet betragtes som svaret på informationsbehovet, og således skal brugeren kun sende sin forespørgsel til systemet én gang førend vedkommende har det rigtige svar på behovet. Der er dermed ikke tale om en egentlig søgepro- 
ces. Denne artikel beskæftiger sig ikke nærmere med den klassiske IR, men anvender den nyere IR-forskning, der anerkender at såvel individets kognitive processer som den sociale kontekst har indflydelse på informationssøgningen. Denne tilgang er bl.a. repræsenteret ved Belkin (1982) og Ingwersen (1992, 1996, 2001).

2. Oprindeligt: "thesaurus".

\section{Litteraturliste}

Allen, B (1997) Information needs: a person-in-situation approach. Information seeking in context. Proceedings on an international conference on research in information needs, seeking and use in different contexts, 14-16 August, 1996, Tampere, Finland. London: Taylor Graham, 111-122.

Allen, BL (1996) Information tasks: toward a usercentered approach to information systems. San Diego, Calif.: Academic Press.

Belkin, NJ; Oddy, RN; Brooks, HM (1982) Ask for information retrieval: part I, backgrounds and theory. Journal of documentation, (38)2, 61-71.

Byström, K; Järvelin K (1995) Task complexity affects information seeking and use. Information Processing \& Management, (31)2, 191-213.

Bødker, K; Kensing, F; Simonsen, J (2000) Professionel IT-forundersøgelse: grundlaget for boredygtige IT-anvendelser. København: Samfundslitteratur.

Dervin, B; Nilan, M (1986) Information needs and uses. Annual review of information science and technology (ARIST), (21), 3-33.

Effektive offentlige arbejdsprocesser: værktøjer (1999) Finansministeriet. http://www.fm.dk/1024/ visPublikationesForside.asp? artikelID $=4146$.

Lokaliseret d. 16.1.2004.
Ellis, D (1989) A behavioural approach to information retrieval system design. Journal of Documentation, (45)3, 171-212.

Ellis, D; Cox, D; Hall, K (1993) A comparison of the information seeking patterns of researchers in the physical and social sciences. Journal of Documentation, (49)4, 356-369.

Friis Jeppesen, H (2003) De higer og søger: En undersøgelse af workshoppens anvendelighed ved design af metadatasystemer. Kandidatspeciale ved Danmarks Biblioteksskole, 2003 (Upubliceret).

Hertzum, M (2000) People as carriers of experience and sources of commitment: information seeking in a software design project. The New Review of Information Behaviour Research; Studies of Information Seeking in Context (1), 135-149.

Hertzum, M (2002) Produktudvikleres informationssøgeadfærd og brug af informationskilder: konsekvenser for+ søge- og informationssystemer. Biblioteksarbejde, (22)63, 21-30.

Holm, S (1997) Kvalitativ forskning. Bibliotek for loeger, 3. http://www.dadlnet.dk/2videnskab/ bibliotekforlaeger/index_dadl.htm.

Lokaliseret d. 6.4.2003.

Ingwersen, P (1982) Search procedures in the library analyzed from the cognitive point of view. Journal of documentation, (38)3, 165-191.

Ingwersen, P (1992) Information retrieval interaction. London: Taylor Graham.

Ingwersen, P (1996) Cognitive perspectives of information retrieval interaction: elements of a cognitive IR theory. Journal of Documentation, (52)1, 3-50.

Ingwersen, P (2001) Users in context. Lectures on information retrieval. Third European SummerSchool, ESSIR, Varenna, Italy, 2000. Heidelberg: Springer-Verlag. 
Kvale, S (2000) Interview: en introduktion til det kvalitative forskningsinterview. København: Hans Reitzels forlag.

Kuhlthau, C (1991) Inside the search process: Information seeking from the user's perspective. Journal of the American Society for Information Science 42(5), 361-371.

Lykke Nielsen, M (2000) Domain Analysis; an important part of thesaurus construction. Classification for user support and learning : proceedings of the 11th ASIS\&T SIG/CR Classification Research Workshop, November 12, 2000 : held at the 62nd ASIS\&T Annual Meeting, November 12-16, 2000, Chicago, Il. [s.1.]: SIG/CR ASIS.

Lykke Nielsen, M (2002) Konstruktion af metadatasystemer. Arkiv: tidsskrift for arkivforvaltning og arkivteknik, (7).

Lykke Nielsen, M; Ingwersen, P (1999) The word association methodology: a gateway to work-task based retrieval. Final MIRA Conference on Information Retrieval Evaluation, $14^{\text {th }}-16^{\text {th }}$ April, 1999, Glasgow, Scotland. [S.1], [s.n].
Nachmias D; Nachmias C (1987) Research methods in the Social Sciences. New York: St. Martin's Press, 3. udgave.

Vakkari, P (1997) Information seeking in context: a challenging metatheory. Information seeking in context. Proceedings on an international conference on research in information needs, seeking and use in different contexts, 14-16 August, 1996, Tampere, Finland. London: Taylor Graham.

Vakkari, P (1999) Task complexity, problem structure and information actions: integrating studies on information seeking and retrieval. Information processing \& management, (35), 819-837.

Wilson, T.D (1981) On user studies and information needs. Journal of documentation, (37)1, 3-15.

Wilson, T.D (1997) Information behaviour: an interdisciplinary perspective. Information processing \& management, (33)4, 551-572.

Wilson, T.D (1999) Models in information behaviour research. Journal of documentation, (55)3, 249-270. 